\title{
Active Debate for Learning Pluralism for Student Candidate of Teachers' Religion
}

\author{
Munardji ${ }^{1}$,Elfi Mu'awanah ${ }^{1}$, Machsun Rifauddin ${ }^{1}$, Rifa Hidayah ${ }^{2}$ \\ (1 IAIN Tulungagung, Indonesia;2. UIN Maulana Malik Ibrahim Malang, Indonesia)
}

\begin{abstract}
Use of active debates to improve understanding of pluralism for prospective religious teacher students through learning the subject of the education profession. The concept of pluralism has been developing for a long time in Indonesia, but its application is still far from expectations. Lack of understanding of pluralism causes inter-religious conflict creating new problems that are detrimental to the state. On the other hand, understanding of the essence and meaning of pluralism is still ambiguous among the people. This study aims to re-explain the meaning of pluralism with an active debate to prospective students of religious teachers because they are holders of security control in society when they become teachers. The results of the study show that through active debate the essence of pluralism can be possessed by prospective students so that they can be predicted to give an example of upholding pluralism which means tolerance between religious people and not always can explain which religion is correct. The concept of pluralism in Indonesia can be implemented by recognizing the existence of other religions, giving the right to coexist with one another, avoiding violence by not destroying places of worship of other religious people, not forcing the will of followers of other religions, recognizing the many ways humans and orders to compete in virtue.
\end{abstract}

Key words: pluralism, active debate method

\section{Introduction}

Nowadays, religious people in Indonesia are faced with the challenge of the emergence of clashes or conflicts among themselves. Understanding the thoughts that exist in students to find out about the existence of prularism in participants is needed as research conducted to determine the thinking of children, whose lives are governed by decisions taken by adults, about the right to self-determination (Pekince \& Avci, 2018) because it is expected to give a positive character to students in the future. The inter-religious conflict that occurs is increasingly alarming, even with the existence of new conflicts, it will be able to penetrate other areas if people easily accept issues and are provoked (Daulay, 2001). The turbulent inter-religious riots have occurred in Indonesia, such as the case of mosque burning that occurred in Tolikara, Papua, or the conflict between Sunni followers and Shiites that occurred in Sampang, Madura, and conflicts involving the Qur'anic Interpretation Council (MTA) and Nahdliyyin residents in Purworejo, Kudus, Blora and Grobogan which were allegedly preceded by provocative values. Cases

\footnotetext{
${ }^{I}$ Munardji coresponding author email munardji@iain-tulungagung.ac.id, Elfi Mu'awanah email elfi_muawanah@yahoo.co.id, Machrun email machsunr@gmail.com, lecture in IAIN Tulungagung Indonesia.

${ }^{2}$ Rifa HIdayah email rifa_hidayah@psi.uin-malang.ac.id, lecture in UIN Maulana Malik Ibrahim Malang Indonesia
} 
of violence carried out by groups in the name of religion are sometimes considered as part of "jihad fi sabilillah", for example, cases of terrorists in various places in Indonesia that began in the era of the 2000s.

Interfaith conflicts generally are not purely caused by religious factors, but by others, such as economic, political, and social factors. Conflict and violence between religious people are often caused by exclusivity and fanaticism which considers religion to feel the most right and considers other religions to be heretical. In fact, violent behavior is sometimes considered a part of jihad. The lack of public knowledge about pluralism gives birth to apathetic and puritan characters towards religious tolerance (Kahmad, 2006). The consequence of the conflict is a total loss in various parties, and even a very large impact is felt by the state. The issue of inter-religious disputes in Indonesia has become national and even international public consumption and will create a bad view of Indonesia. Indonesia is considered not serious in handling cases of riots that occur, so it is claimed to be a dangerous or unsafe country. This can arouse suspicion or even distrust from the international community towards Indonesia so that relations between the countries that have been established have long been disrupted. Based on the above phenomena, at least the initial conclusions can be taken that until now, awareness of pluralism in religion in Indonesia has not been carried out optimally by society and religion is often used as a tool to create conflict by irresponsible parties. Even though religious values should be released from all personal or group interests, and religion is not used as a tool for achieving certain goals. Religious values need to be read as a source of inspiration and guidance, as well as the main reference for overall behavior and action (A'la, 2002).

Responding to the tilted issue about Islam as an anarchist religion, religious terrorist religion that teaches inter-group war and debate, the researchers try to reexamine the concept of pluralism, until differences of opinion occur on the concept of pluralism. There is a view that says that all religions are the same. This kind of thinking has long developed in Indonesia and several other Islamic countries (HM. Yasin, 2003). On the other hand, it is argued that religious pluralism in Islam recognizes the diversity of religions, but it does not mean that he approves of the same truth between religions, thus making the unity of religions a way to God's truth (As'ad, 2012). Regarding differences in understanding between the meaning of pluralism and religious pluralism, and how the concept of pluralism according to Islam. This research is considered important to re-explain the meaning of pluralism and religious pluralism and to apply the concept of Indonesian pluralism.

\section{How Pluralism as Worldview for Student Candidate Teacher of Religion}

Many western thinkers and theologians see that the notion of religious pluralism is the only way out to deal with mutual hostility and intolerant attitudes of religious communities and can reduce tensions between the West and the Islamic world (Jamaludin, 2013). The Idea of Religious Pluralism was born and emerged from the notion of "political liberalism" and was an attempt to lay the theoretical foundation in Christian theology as well as a reform movement in the delivery of religious liberalization launched by the Christian Church in the 19th century in the "Liberal Protestantism" movement (Fitriyani, 2011). Religious pluralism is a religious philosophy that originated in the West and was systematically introduced by John Hick (1989) through his work An Interpretation of Religion: Human Responses to the Transcendent. In Global Theology (Global Theology) formulates a theological revolution from the concentration of religions to God-centeredness. In addition, Hick also views that religions are the reality of different human cultural responses from One Real (The Real). With this theory, Hick wants to emphasize that the truth of religion is not monolithic or singular but is plural (Sociological Religious Pluralism in Indonesia (Khaerurrozikin, 2015). This theory would like to emphasize that all religions are actually 
nothing but a manifestation of one reality, so that all religions are equal and there is nothing better and want to relativize the view that all religions are true (Diamandopoulos \& Green, 2018).

Religious pluralism can be divided into three categories, secular humanism, global theology, and syncretism. These three studies ultimately end in the same estuary, namely legitimizing the equals of all existing religions (all schools and ideologies) in order to live side by side. At least this is what these trends want to be realized (Thoha, 2007) lism means an understanding that recognizes the existence of diversity or different existence. Whereas religious pluralism is a concept that has a broad meaning, related to acceptance of different religions, and is used in different ways. The nature of pluralism is a will of God that creates human beings who do not only consist of one group, ethnicity, color and religion. Every religion has different concepts regarding pluralism which in essence pluralism aims to create peace, create a sense of security, comfort, in adhering to and believing in the religion that is believed. Pluralism is a manifestation of "hablum minan nas" (human relations) which is manifested by tolerance and mutual respect and love for the realization of peace on earth.

And ideally this value is invested since the child has primary school education giving students a solid foundation for their next education (Allen-Lyall, 2018). Education is the main tool of social development, a systematic teaching process to transfer some knowledge and skills. The choice of teaching methods affects the level of perception of information by students (Mikerova G., Sergeeva B., Mardirosova G., Kazantseva V., \& Karpenko, 2018). Much more important is the planting of values channeled by the teacher in the learning process including the value of pluralism so that there is no discrimination in learning. The teacher is an agent of behavior change for students, so the importance of providing pluralism for prospective teachers is so that when they become teachers in schools they can expel pluralism in learning and make themselves agents of change including being agents of the value of pluralism in learning.

Reminding the concept of pluralism has become the constitutional philosophy of the world community today, which is a consequence of people living in the era of globalization. An understanding of true pluralism has long been introduced to Indonesian society. The research question is how to grow the ability of prospective teachers to have pluralism awareness which can later be developed in the schools of each place he teaches. How will future teachers stimulate the habit of thinking plural in social life in the future? Teaching pluralism in the subject of school teacher profession candidates, predicted by researchers to be effective in increasing the pluralism awareness of prospective religious teachers living in an era of religious pluralism and preparing religious teacher candidates (Lane, 2019) ready to plunge into the community of the main school where they teach in the future.

\section{Methodology}

\subsection{Subject}

This research was carried out at the college site which produced religious teacher candidates in the IAIN Tulungagung, mainly students who take the teaching profession course 58 students consisting of 2 classes totalling $28 \mathrm{VG}$ class students and $30 \mathrm{VA}$ class students, learning subjects 2 classes 76 students consisting of 37 VF class students and $39 \mathrm{VB}$ class students, eyes 55 lecture source and media learning courses consisted of 2 classes totalling $29 \mathrm{VC}$ class students and $26 \mathrm{VE}$ class students, 72 Islamic religious learning (PAI) design courses in 2 classes totalling 39 VD classes and 33 VG class students, Quran Hadist learning designs 71 students with details of 2 classes totalling $31 \mathrm{VH}$ class students and 40 class VI students) and were taught by the researcher in the odd semester, because the researcher taught the subject and represented all classes. In addition to these reasons, 
research is the duty of a lecturer to participate in developing themselves and to increase the use of self-resources for themselves and their community in campus communities. Thus the sampling of this study was purposive sampling which amounted to 332 students from class V or semester and subjects taught by researchers.

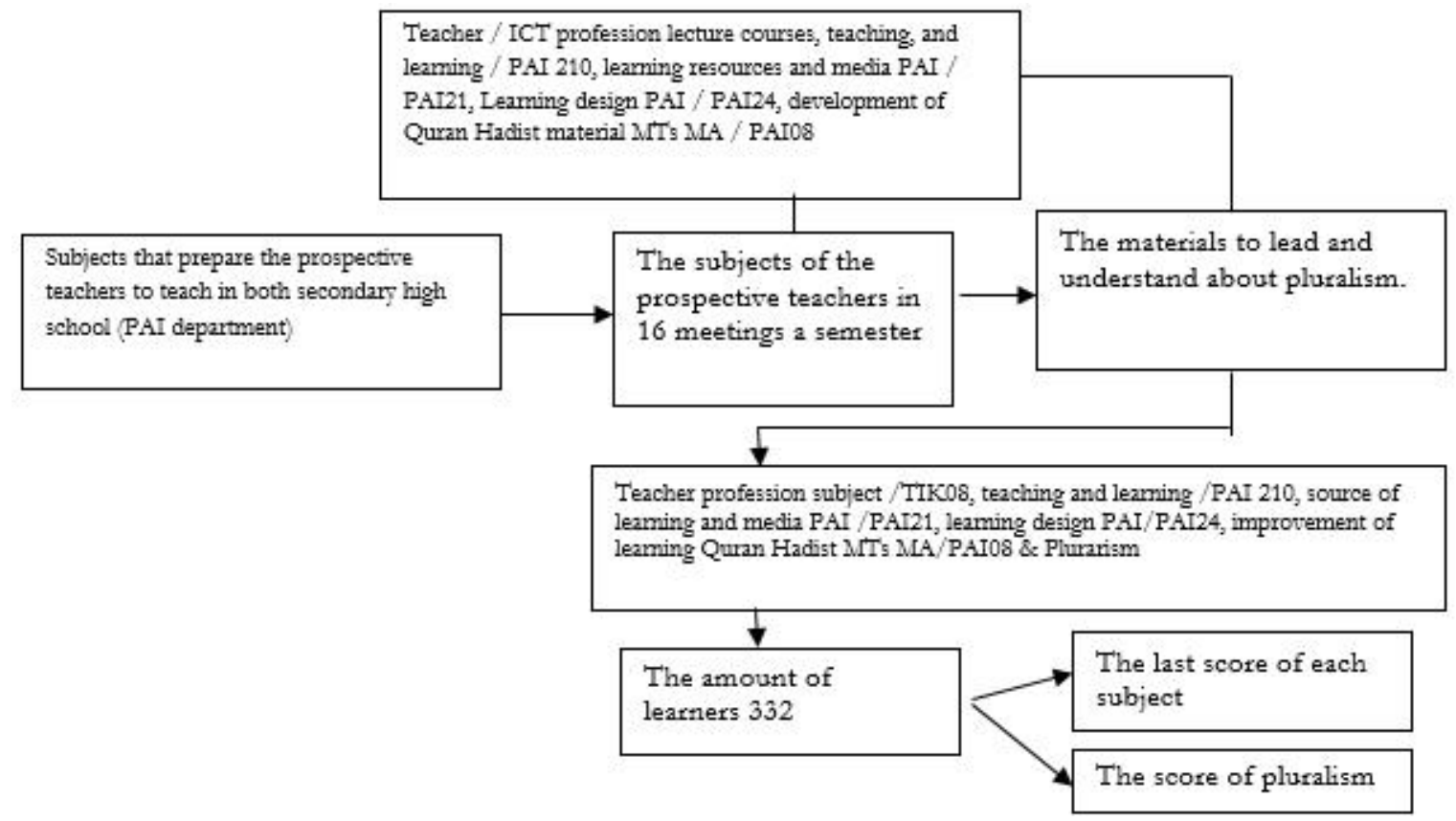

Figure 1 Collaboration of All Subject

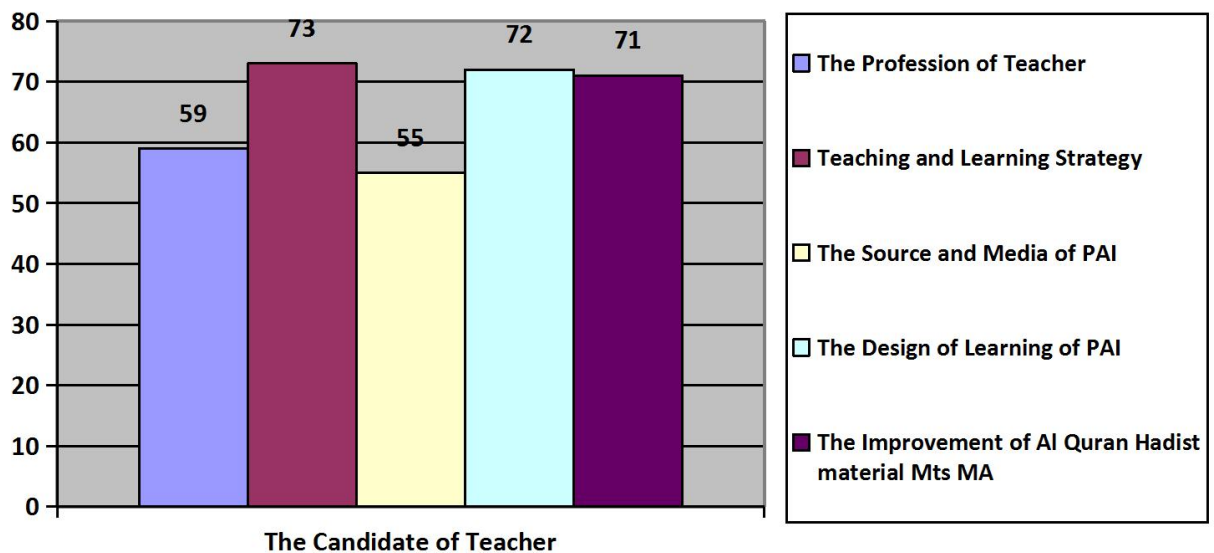

Figure 2 The Number of Prospective Teachers/Students Involved 332 in the Study

There are 66 students who need to be educated for prospective Mts MA religious teachers in Tulungagung IAIN weighing 151 credits. The 5 courses were chosen because this course was given to researchers. Because the expert researcher is the science of Islamic education, all material related to education provided to researchers can be carried out. Being a teacher is to be the leader of oneself and other people, so also the researchers did in giving the subjects taught. Teaching prospective teachers are teaching students who will transmit knowledge gained to others in the future. Being a substitute teacher also empowers her to become the leader of her students later in the class. The teacher as a leader will influence the learners on the effectiveness of the learning outcomes of their 
students. The researchers themselves are leaders for students who are looking for researchers who support students to find specifics who can apply, learn about the results of the PAI study. Students who graduate will be able to learn and compete with other graduates to get jobs or create jobs in the future.

Thus through this course, the achievement of the results of the course specifications with an important pluralism mission is given so that they are able to overcome the future and face the society in the future. Through mastery of courses and pluralism at least will help students to become leaders in the future and be successful and encourage students to be creative, innovative, and dare to take risks in leadership activities that support in the pursuit and help in the future community. In the context of management education, the teacher discusses educators, managers, administrators, supervisors, leaders, innovators, and motivators because it is the capital needed to be needed in the future. It's support creative pedagogy can introduce emotional dynamics into learning, which can be challenging and risky for some students (Sunley, Harding \& Jones, 2019). Through mastery of culinary and pluralism, students should also be able to have tough personalities to face the lives of future people and prospective students, which may vary in diversity and belief. So that the prospective Islamic religious teachers are expected to be ready to condition themselves and the academic community in their teaching with full confidence and responsibility for developing students in the future.

All the classes taught by the research were used as researchers as research subjects to streamline the importance of pluralism in social life. Moreover, Indonesian people who have many religions and beliefs, the religion teacher should have the lens of pluralism in classroom learning. The choice of IAIN Tulungagung by researchers as research subjects was that Tulungagung IAIN had a number of students of approximately 12.000. Students in all majors and study programs totalling 32, where IAIN scored approximately 5000 religious teacher candidates in elementary, middle and high school. Increasing the ability of pluralism is an effort predicted by researchers to increase the competitiveness of prospective religious teachers in the community later in facing the times.

\subsection{Procedures}

This study wants to apply pluralism awareness to students who are studying courses in the teaching profession, learning and learning, PAI learning resources and media, PAI learning design, development of Quran Material and Hadith MTs MA. Giving the lecture material simultaneously or integrative the researcher teaches about the subject matter and pluralism. Learning guide and linking each subject.

Teaching the subject of teacher profession/TIK profession lecture courses, learning and learning/PAI 210, learning resources and media PAI/PAI21, learning design PAI/PAI24, development of Quran material Hadist MTs MA/PAI08 adjusting to the syllabus of the course then determine the formulation of learning, and elaboration of pluralism in face-to-face lectures, selection of learning strategies, and evaluations conducted by each subject and evaluation of pluralism taught.

\subsection{Assessments}

Assessment consists of scoring related to the teacher/ICT08 professional courses, teaching and learning/PAI 210, learning resources and media PAI/PAI21, learning design PAI/PAI24, development of Quran Hadist material for MTs MA/PAI08 Lectures on teacher/ICT professions 08 learning and learning/PAI 210, learning resources and media PAI/PAI21, learning design PAI/PAI24, development of the material of Quran Hadist MTs MA/PAI08 and assessment of the level of pluralism awareness of prospective Islamic education students. Assessment is related to mastery of subject matter and assessment related to pluralism. 
Table 1 Assessment

\begin{tabular}{|c|c|c|c|}
\hline Subject & The Aim of the Assessment & Assessment form & Scoring \\
\hline Teacher profession & $\begin{array}{l}\text { Understanding the teacher } \\
\text { profession }\end{array}$ & 4 items essay & $\begin{array}{l}\text { The description of the answer shows a } \\
\text { logical argument that will get the maximum } \\
\text { value }\end{array}$ \\
\hline Teaching and learning & $\begin{array}{l}\text { Understanding and knowing the } \\
\text { weaknesses and strengths of } \\
\text { teaching and learning strategies }\end{array}$ & 4 items essay & $\begin{array}{l}\text { The description of the answers shows the } \\
\text { skill and accuracy of choosing to teach and } \\
\text { learning strategy gets the maximum value }\end{array}$ \\
\hline $\begin{array}{l}\text { Sources and media of } \\
\text { learning PAI }\end{array}$ & $\begin{array}{l}\text { Understand and compile the } \\
\text { media used in learning }\end{array}$ & $\begin{array}{l}\text { Making the media } \\
\text { of learning }\end{array}$ & $\begin{array}{l}\text { The suitability of media selection in } \\
\text { accordance with the teaching material, the } \\
\text { quality of media making has the maximum } \\
\text { value }\end{array}$ \\
\hline Learning design of PAI & $\begin{array}{l}\text { Arrange RPP PAI according to the } \\
\text { curriculum }\end{array}$ & $\begin{array}{l}\text { Making the lesson } \\
\text { plan of PAI }\end{array}$ & $\begin{array}{l}\text { The order of the RPP structure and the } \\
\text { suitability of the contents of each RPP } \\
\text { structure get the maximum value }\end{array}$ \\
\hline $\begin{array}{l}\text { The Improvement of } \\
\text { materials PAI }\end{array}$ & $\begin{array}{l}\text { Compile the Qurdis lesson plan } \\
\text { according to the curriculum }\end{array}$ & $\begin{array}{l}\text { Making the } \\
\text { Lesson plan of } \\
\text { Quran Hadith }\end{array}$ & $\begin{array}{l}\text { The order of the RPP structure and the } \\
\text { suitability of the contents of each RPP } \\
\text { structure get the maximum value }\end{array}$ \\
\hline Pluralism & $\begin{array}{l}\text { Having understanding } \\
\text { awareness of pluralism and } \\
\text { applying it in everyday life. }\end{array}$ & $\begin{array}{l}\text { Portfolio of } \\
\text { events about } \\
\text { pluralism }\end{array}$ & $\begin{array}{l}\text { Exposure to the portfolio of pluralism that is } \\
\text { lived in daily life as indicated by pluralism } \\
\text { gets maximum value }\end{array}$ \\
\hline
\end{tabular}

As for the assessment related to the subject of teacher training, teaching and learning strategies, learning media, PAI design, the Quran Hadist design is: a) to assess the condition of class rankings and/or student position in the classroom, as well as mastery of students in teacher training material, teaching and learning strategies, learning media, PAI design, Quran Hadist design and A + (4) A (3.5) A- (3) B score (2.75). Assessment in the form of questions related to the course. The assessment related to pluralism is the answer to questions related to questions that examine the extent to which a student's awareness of solving problems related to pluralism. As for this assessment, the final value of pluralism awareness lies in the answers given the given values A + (4) A (3.5) A-(3) B (2.75). Then the value of the course and integration assessment and the final value of the course because in the curriculum, pluralism is a perspective that needs to be possessed by a prospective teacher, especially when he teaches children who are prepared to face the conditions of the growing age.

\subsection{Active Debate Method for Leaning Pluralism}

In face-to-face approximately 16 times lecture face-to-face learning process for each subject studies including assessment according to the schedule made by the academic section of IAIN Tulungagung, prospective teachers are taught courses and added material related to the themes in the order for example. Among the 16 face-to-face lectures, $10 \mathrm{x}$ meetings were inserted in the concept of pluralism.

Pluralism treatment material which is inserted interactively in the subject of teacher professions value and awareness of pluralism of the teaching profession material, teaching and learning strategies, PAI learning resources and media, PAI learning design, Quran Hadist design as shown in Figure 3.

The material related to the increase of religious pluralism awareness integrated into the learning of subjects taught by researchers is as follows.

\subsubsection{Face to Face Inserts $1 \& 2$ : Sessions Recognize the Existence of Other Religions}

Students are invited to see the phenomenon of the existence of a religion other than Islam in Indonesia. If the doctrine of religious pluralism must recognize the truth of other religions, Islam only recognizes the truest Islam in the sight of Allah "in fact religion (which is accepted) by Allah is Islam". But Islam upholds tolerance. Even tolerance (tasamuh) is a characteristic of Islam itself (Khaerurrozikin, 2015). Pluralism is not a religious equation, 
but rather an understanding of the legitimacy of each religion that is different from Islam (Firdausia, 2013). Recognizing the existence of other religions does not mean that other religions are right, but considers that there is a difference (religion), therefore the value of tolerance must be upheld so as not to cause conflict and division.

Tabel 2 The Number of Face to Face Lectures

\begin{tabular}{cccc}
\hline Meeting & Subject (5 subjects) & Timeline for main learning & Timeline for pluralism \\
\hline 1 & Topic 1 & 150 minute & No minute \\
2 & Topic 2 & 150 minute & No minute \\
3 & Topic 3 Pluralism 1 & 115 minute & 35 minute \\
4 & Topic 4 Pluralism 2 & 115 minute & 35 minute \\
5 & Topic 5 Pluralism 3 & 115 minute & 35 minute \\
6 & Topic 6 Pluralism 4 & 115 minute & 35 minute \\
7 & Topic 7 & 150 minute & No minute \\
8 & Mid-term/Assessment & Take home & Take home \\
9 & Topic 8 Pluralism 5 & 115 minute & 35 minute \\
10 & Topic 9 Pluralism 6 & 115 minute & 35 minute \\
11 & Topic 10 Pluralism 7 & 115 minute & 35 minute \\
12 & Topic 11 Pluralism 8 & 115 minute & 35 minute \\
13 & Topic 12 Pluralism 9 & 115 minute & 35 minute \\
14 & Topic 13 Pluralism 10 & 115 minute & 35 minute \\
15 & Topic 14 & 150 minute & No minute \\
16 & Final Examination & 75 minute & 75 minute
\end{tabular}

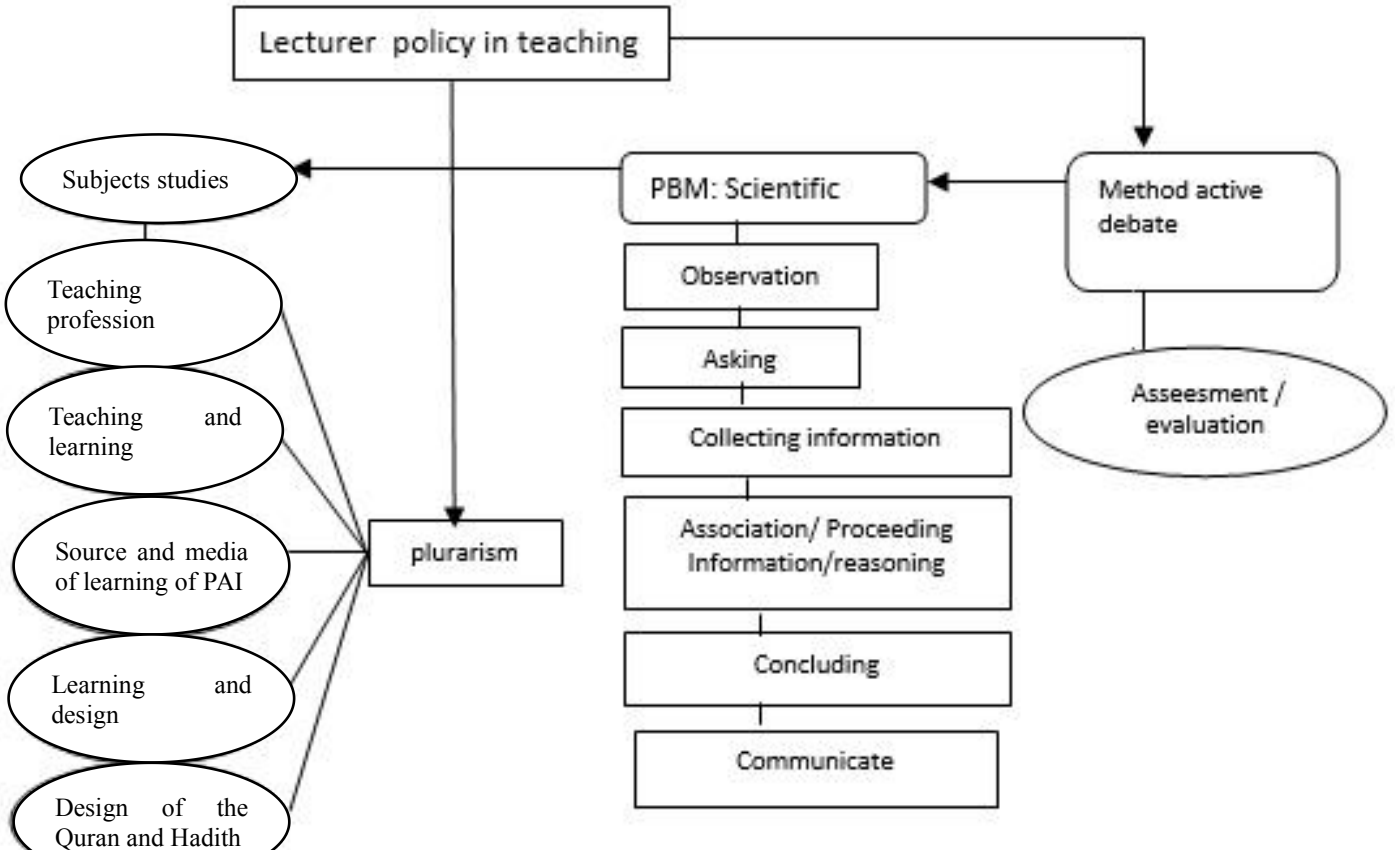

Figure 3 Pluralism in Learning 
3.4.2 Face-To-Face 3 \& 4 Inserts: Sessions Provide the Right to Mutual Respect for Followers of Other Religions

Students understand that religion is the right of all humans. Moreover, Indonesia has thousands of islands inhabited by hundreds of ethnic groups. It is very possible if an area is inhabited by various tribes with various kinds of different religions. A nation may have the same culture which is a reflection of traditions that develop in the community, but a nation does not have to have the same religion. The spirit of pluralism tolerance and culture is built on the basis of the awareness of religious people in carrying out daily life both work and worship problems, someone must interact and interact with each other. Harmony and comfort in worship will not be realized without tolerance and mutual respect for each other's interests. But sometimes this good relationship between religious communities can become a conflict if peace and comfort in worshiping one congregation is criticized by other people who are not responsible, this usually occurs between the majority and the minority. However, the possibility of political and social factors can also be a major factor in the creation of the riots. One effort that can be done to prevent the riots is to give the right to coexist and respect each other among followers of other religions.

3.4.3 Face to Face 5 \& 6: A Session to Avoid Violence by Not Destroying Places of Worship of Other Religious People

Invite students to avoid and even if they can stop damaging places of worship of other religions. Every religion in Indonesia has its own place of worship, such as Islam has a mosque, Christians and Catholics have a church, Hindu has a temple, Buddha has a temple and Kong Hu cu has a temple. Every place of worship is sacred and becomes an identity of religious progress. Because every religious community considers its place of worship as a sacred and sacred place, they are competing to build with magnificent the place of worship. The struggle for pluralism is closely related to the struggle against violence (Anna, 2012). The tradition of Islamic tolerance of non-Muslims is a reality that can be traced through revelation; the Qur'an and al-Hadith, and the history of civilization inscribed by the Khulafa "Rashidin, then Umawiyah", Abbasid, Utsmaniyin, and other Islamic kingdoms; in Dar Islam, there are mosques, churches, synagogues; in which can be heard the call to prayer and the sound of church bells. Non-Muslim minorities are guaranteed protection and security and are given the freedom to practice their religious rituals.

3.4.4 Face-to-face inserts to $7 \&$ 8: The Session Does Not Impose the Will on Followers of Other Religions

Students are invited to discuss not to impose the will on followers of other religions. Al-Quran explicitly teaches that in choosing religion, humans are given the freedom to understand and consider themselves. In understanding this, Thabathaba'I (1883) argues that because religion is an ilmiy series. Al-Qur'an explicitly teaches that in choosing religion, humans are given the freedom to understand and consider themselves. In understanding this, argues that because religion is an Islamic series followed by amaliyah (manifestation of behaviour) into one unity i'tiqadiyah (belief) which is a matter of the heart, then religion cannot be forced by anyone. Recess is an integral part of a school day where children are given the opportunity to make and organize games, socialize with their peers, and explore nature (Stapp A. C. \& Karr, 2018).

3.4.5 Insert Face Number $9 \&$ 10: The Session Recognizes the Many Ways Humans Can Go and Orders to Compete in Virtue

Invite students to do the other side in kindness. Al-Banna (2006) asserts, that the Qur'an never requires humans to be one people governed by one convention or one idea. The magnitude of the Qur'an's appreciation and 
attention to religious pluralism is shown in Surat Al-Baqarah verse 148. "And for each people, there is a qibla (itself) which he faces to him. Then compete with you (in doing) virtue (Q. S. Al-Baqarah, p. 148). Explained in the verse that every religion has its own beliefs and teachings. Our duty as adherents of Islam is how to become a good Muslim by improving ourselves and always increasing faith in Allah and His Prophet, understanding and practicing the teachings of Islam without having to disturb the peace of other religions. Each religious community has its own qibla and a qibla that the believers have shown by the Messenger of Allah on the guidance of Allah.

\subsection{Data Analysis}

Data analysis in the form of student answers to the results of assessment/UAS/final results of the courses taken and the results of the final value of pluralism. The researcher reads the results of the student answers then the main answers to the student's ideas with the main indication of the answers to each question given in each course and the quality of answers according to the assessment standard whether the student is given a value of 4 for the highest quality answer equivalent to $\mathrm{A}+, 3.5$ for the answer quality equivalent to value $\mathrm{A}, 3$ with quality value A-, or 2.75 with value B. Pluralism portfolio data according to indications that have been determined by the researcher whether it can be answered by students or not later from the results of the answers the researcher assesses the quality of answers and answer standards then students are given grades 4, 3.5, 3, or 2.75. A+, 3.5 for answer quality equivalent to value A, 3 with quality value A-, or 2.75 while with value B

3.5.1 Active debate for the pattern of active debate method in the class used is as follows

An active debate is chosen to provide pluralism because through active debate students are trained to find and think and change their minds, sketches and problem solvers (Maxville, 2010). Both the consensus model of teacher knowledge and skills as well as the constructs that pay attention to the teacher provide a strong foundation Both focus on pedagogical knowledge or the role of this knowledge in teaching practices and student outcomes (Auerbach \& Andrews, 2018).

Asking students to engage in generative work in large courses raises different logistical challenges from college (Alruthia et al., 2019). In active debate, it is necessary to note how the active debate process will proceed, the time of each participant in delivering arguments, and most importantly, the assessment in which one group can strengthen each other's arguments in the team. Auerbach \& Andrews (2018), show how contrasting views can complement each other (Ghislaine Gueudet, Marianna Bosch, Andrea A. diSessa, 2016). Various active learning techniques have been described in the literature. The most common class-based active learning strategies include one of them is active debate (Alruthia et al., 2019). However, the linkages between higher education and democracy have surpassed the opportunities for improving life. In particular, higher education has been seen as a vehicle to enable people to be more open and rational. the issue of pluralism is part of the manifestation of democracy that can be instilled in high society and active debate is the right method for learning democracy (Barnett, 2019). Question and answer is an integral part of learning that allows facilitation of self-exploration of learning narratives which are key in influencing temporal immersion and important in the method active debate (Ioannis Doumanis, Daphne Economou, Gavin Robert Sim, 2019). Debates refer to structured processes discussing various points of view. Active participants in a debate take a stand on a problem or question presented and use persuasive communication, evidence, and logic to direct others to agreement. Debates can be used to build knowledge about a subject, develop critical thinking and analysis of literature, improve communication skills, and develop other soft skills such as persuasiveness and teamwork (Dy-Boarman, Nisly, \& Costello, 2018). This 
difference between the trajectory of universal and non-universal cognitive development is important not only because it provides a way for teachers to think about debates about learning and development, but also because it provides a deeper understanding of the dynamic nature of development and thus facilitates a nuanced approach. for instructions (Fowler, 2016). Although both will agree that, to promote critical thinking, criticism and discussion must penetrate the classroom, they have different narratives about how a critical atmosphere affects children. For Piaget, teachers develop a critical environment to enable children to build their own tools that will change themselves from within (Fowler, 2016).

To illustrate the use of debate, and to evaluate student performance and perceptions, when student debates are included as active learning tools in the required pharmaceutical health service delivery courses. Debate, which is defined as "formal discussion of a particular problem in a public meeting or legislative council, where opposing arguments are put forward and which usually ends with an assertion that fits the topic and purpose of learning. Active debate has been used as an active learning strategy in various disciplines different, live or online debate formats, based on individuals or teams, and different assessments of the usefulness of active learning tools, effectively for active debate to stimulate interest, encourage active class participation, and improve presentation skills, research, and critical thinking skills in a professional program, the use of active student debates to provide different arguments according to the theme presented in an active debate session is also needed to increase students' awareness of views that conflict with the theme or agreement with the theme with them. give an argument within a certain time limit (Peasah \& Marshall, 2017).

In active debate students will be trained to "see" or "hear" other participants in the process of "talking" and spending the specified time, by and therefore it is very likely that someone can interfere with the answers of others, creating a number of parallel threads support each other, and or fight with each other. The class of roles students must adopt is the role of argumentation. In creating a community with the aim of developing a critical understanding of a subject, it is important to encourage students to explain and justify their reasons and play a role in discussion (Pilkington \& Walker, 2003). The "role playing" activity was designed and used with the student class in this farce play paired with other students in one group agreeing with the theme and one group did not agree with the theme of pluralism, then the two groups faced each other to strengthen their respective arguments. The superiority of active debate is that many thoughts emerge supporting the theme of pluralism and increasing awareness of the importance of pluralism and as a provision later when the prospective religious teacher students become teachers in society today and in the future and practice giving criticism with a logical basis (Spence, 2019).

\subsubsection{Formulation of Active Debate Method in Pluralism Learning in the Classroom}

As for the learning outcomes of teacher training professions in one semester and the results of the understanding of pluralism through the subject of teacher training can be seen in Figure 5 . 




Figure 4 Formulation of Active Debate Pluralism Learning in the Classroom

\section{Findings and Discussion}



Figure 5 Final grades of Teacher Professional Courses and Pluralism

Figure 5 shows the value of the teaching profession and pluralism courses from 58 people are as follows. Students who get the value of 4 teacher training professions are 15 and the value of pluralism is 14 students. Students who received a score of 3.5 totalled 13 and pluralism scores amounted to 15 students. Students who take the teaching profession courses and get 3 grades totalling 15 and the pluralism scores of 17 students and students who get a score of 2.75 are 5 and the pluralism scores are 2 students. According to (Madjid, 1992) pluralism can be taken through three religious attitudes namely the first exclusive attitude in seeing other religions; this attitude views other religions as the wrong way, which misleads the people. Second is an inclusive attitude; this attitude views other religions as an implicit form of our religion. The third is pluralism; this attitude can be expressed in various formulas, for example, "other religions are equally legitimate ways to achieve the same truth", "other 
religions speak differently, but are equally valid truths", or "every religion expresses an important part of a truth". Thus through the hands of a prospective teacher at least through the value of pluralism even though there is no special subject but by integrating it in a course it is predicted that it can provide insight to prospective teachers who live in the middle of a country where various religions live it will be able to create harmony in religion.

As for Figure 6 for learning and learning courses and pluralism are the following students who get 4 grades totalling 15 while students who get 4 pluralism scores are 18 students. The value of teaching and learning strategies that get 3.5 scores is 23 and the value of pluralism is 25 students. The students who got 3 grades were 25 and the pluralism scores were 25 students. While there were 13 students getting a score of 2.75 and a pluralism score of 9 students as in Figure 6.

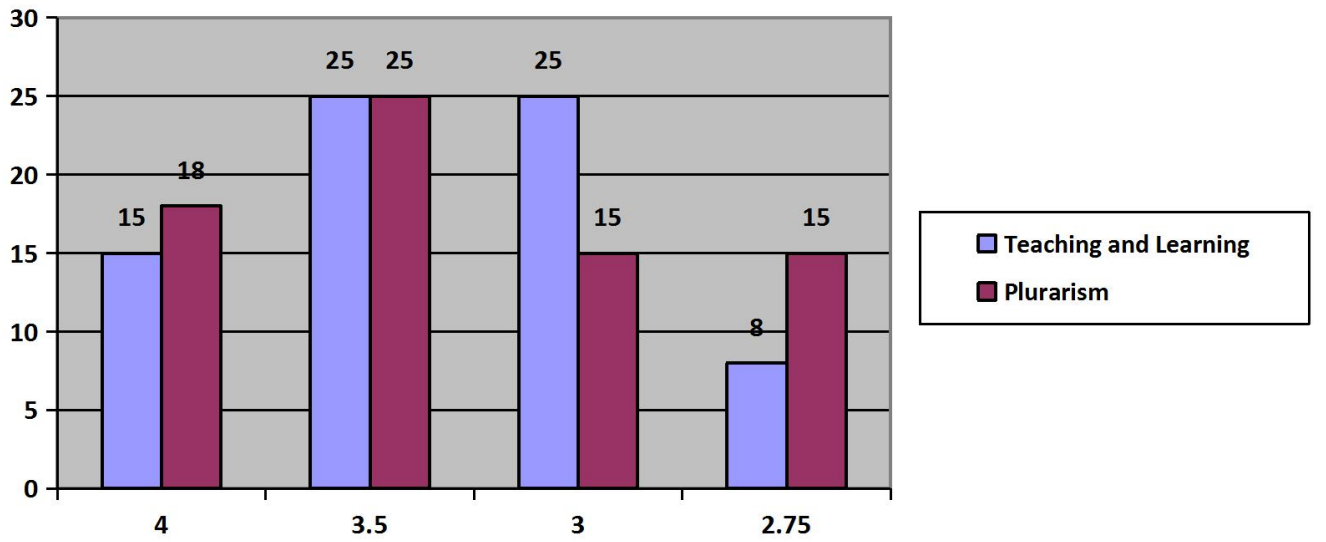

Figure 6 Value of the Lessons of Learning and Learning \& Pluralism

The Figure 7 for the source and PAI media and pluralism subjects is as follows. Students who get 4 grades are 15 and students who get pluralism score 4 are 20. Students who get the value of learning media 3 are 20 and the value of 4 pluralism is 18 . Students who get a value of 3 are 15 and the value of pluralism is 14 . Students who get grades 2.75 in the subject of learning media totalling 5 and the value of pluralism 2.75 is 3 as Figure 7 .

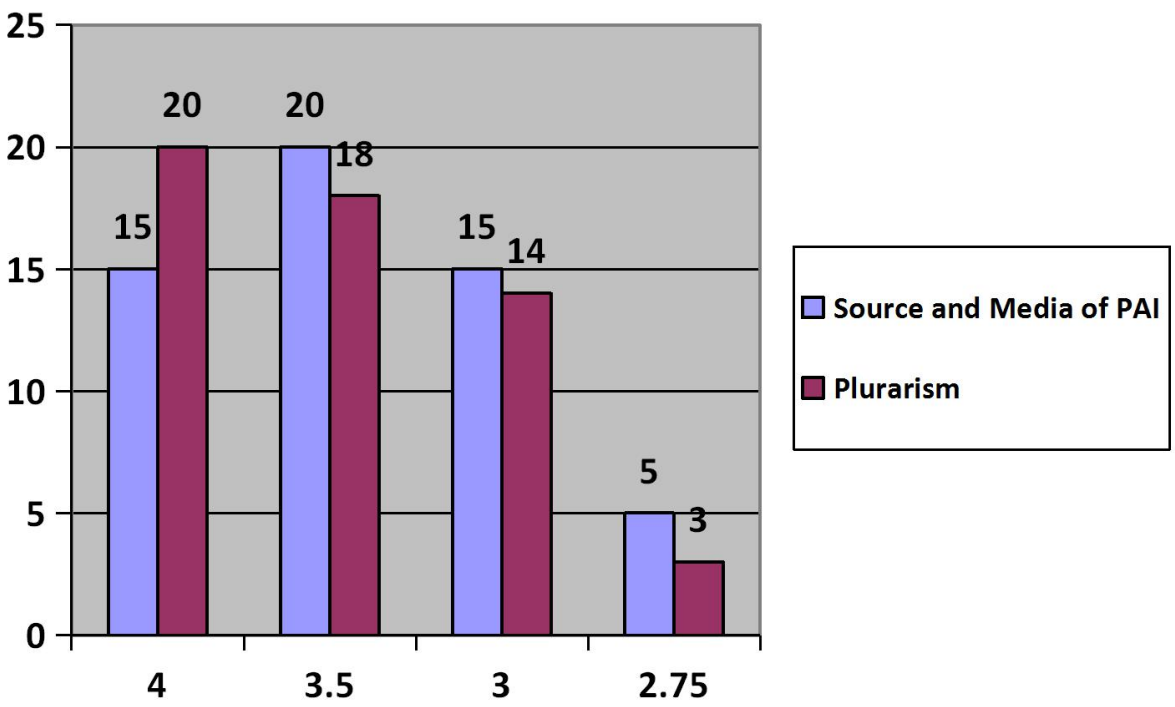

Figure 7 Final Value of Subjects Sources and Media for Learning Islamic Education and Pluralism 
The final grades of PAI Learning design students who get 4 grades are 20 and those who get pluralism score 4 are 19, students who get 25 learning PAI 3.5 design subjects and 27 pluralism courses. For final grades of PAI student learning design courses who get 3 grades totalling 19 and the value of pluralism 3 is 18 students. For the final score of PAI 2.75 learning design courses are 8 students and the final grade of pluralism 2.75 obtained by 8 students as can be seen in Figure 7.

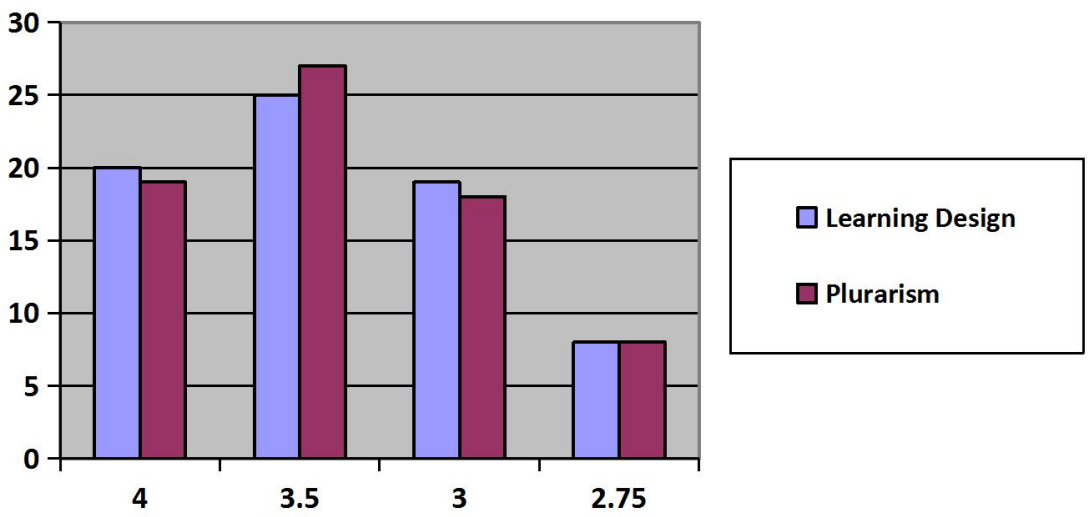

Figure 7 Final Value of PAI Learning Design Courses and Pluralism

The results of the subject value of the development of Quranic Material Hadith Mts MA in Figure 8 which gets the value and pluralism are as follows. The value of learning Quran hadiths that get 4 grades is 20 students and the value of pluralism which gets 4 grades is 22 students. Students who get a score of 3.5 are 20 and students who get pluralism 3.5 amount to 19. There are 20 students who get Qurdist Material Development Mts Material Development and 20 students get 19. Pluralism scores 2.75 Qurdist Material Development Mts MA students number 11 and the value of pluralism is 11 .



Figure 8 The Results of the Subject Value of the Development of Quranic Material Hadith Mts MA

From all incoming value, data can be described in Diagram 1 which shows the value of A for 5 subjects obtained by students as much as 85 , value B. There are several types of institute (INS) courses, PAI (PAI) courses, special subjects (ICT), which total 66 courses. To become a PAI teacher, every student is required to take all these courses. No less than 600 lecturers teach at faculty tarbiyah consisting of biology, Indonesian, Management, English, Arabic, PGMI, PAI, Mathematics, all those who attend the study program are prepared to become teacher candidates according to the specifications of each choice on the school track. Elementary, secondary and high 
school. Students who take PAI semester V courses are chosen by researchers because when teaching subjects they are important to provide an understanding of pluralism. Considering the relationship between religious people mutual respect and harmony is an interesting phenomenon amid the plurality of societies. But the harmony between the religious communities will fall apart due to a lack of tolerance that causes conflict. The trigger factors for the conflict are more due to religious issues. There are 66 courses that must be mastered by prospective religious teachers PAI IAIN Tulungagung study program. Courses are arranged to provide students with professional, professional, personality and social attitudes. But what is specific to pluralism is that none of the courses contain the value of pluralism. While ironically, religion is often used as a propaganda tool on economic and political issues so that religion loses its function as a guardian of love and salvation amidst a social system that is hungry for wealth and power. Plurality is essentially the reality of life itself, which cannot be avoided and rejected (Fitriyani, 2011).

The process of learning courses is carried out according to the topic of each subject, then some face-to-face interspersed with pluralism. Remembering that Indonesians are also thinking about how to include anti-corruption in a high-ranking university, as revealed by the university's 21st December 2019 TV trans at 8:00 p.m. where an anti-corruption score can be taken. The insertion of material both pluralism, anti-corruption, anti-terrorism indeed needs to be done considering the condition of the Indonesian people and the occurrence of various inequalities in the community. Thus the pluralism material given to 5 courses to equip prospective religious teachers is an effort to maintain the continuity of the unitary state of the Republic of Indonesia. The points in the course can be conveyed pluralism messages can also be accepted by prospective PAI teacher students. The values obtained by students in the subject of the teacher/ICT08 professional course, learning and learning/PAI 210, learning resources and media PAI/PAI21, learning design PAI/PAI24, development of Quranic material Hadist MTs MA/PAI08 Lectures on teaching professions/ICT08, learning and learning/PAI 210, learning resources and media PAI/PAI21, learning design PAI/PAI24, development of the material of the Quran Hadist MTs MA/PAI08 each of the two classes. The UNIKAMA has implemented anti-corruption in its identity course (Nasrudin, 2015) than any character, especially in this study, is pluralism implemented as an insertion program for subjects in the subjects is a need to prepare for the future of future religious teacher candidates.

Even though the trend of thinking is always developing and one of the requirements for the realization of a democratic modern society is the realization of plurality-valued societies (Madjid, 1992), it needs to be continuously fostered for students who later become elements of society and nation and realize as a necessity of the community model pluralism in the future. At present, it is also an era of democracy that will never be separated from pluralism. Between democracy and pluralism have a reciprocal relationship, without democratic national pluralism, it will not be built otherwise without democracy the concept of pluralism will not be realized. Students in their portfolio of analysis of assessment answers in various perspectives on student answers indicate their readiness in understanding religious pluralism in Indonesia, which has been disseminated by liberal Muslims and even religious leaders through liberalization of Islamic thought on the pretext of tolerance. However, what is discourse is Islamic theological doctrine with statements that conflict with Islamic teachings (Khaerurrozikin, 2015). From the portfolios analysis, it was also found that the students' answer was that the forced idea of a pluralist thought and society (that all religions are the same and aimed at achieving the same god), who later understood, tried to invite every believer to not claim that religion was the truth and others were wrong (Afrizal, 2011) and helping students understand the position and the most important thing was still to convey the truth of the problem as a result of the community's response that it was not a matter for students or prospective religious 
teachers. From the answers of the student portfolio, the students' understanding of the meaning of pluralism is different from the concept of religious pluralism (Hick, 1989), for example, Fitriyani (2011) defines plurality of religion as a coexistence between religions (in a broad sense) that vary in one community while maintaining the specific characteristics or teachings of each religion.

In the portfolio answer, it can also be analyzed that an understanding has been formed after the pluralism treatment to students that the existence of those who reject religious pluralism is considered to be a conservative, old-fashioned group and does not follow the flow of progress. This is because they are considered to have rejected religious diversity and religious tolerance (Muammar, 2012) is something that needs to be faced later in the field by giving more innovative expression and aspiration as a challenge for future religious teachers. From the portfolio analysis, it can also be seen that it is understood that pluralism is different from the understanding of religious pluralism. The emergence of the notion of religious pluralism has led to the pros and cons of Muslim scholars in Indonesia. Religious pluralism is not the right solution to reconcile religious people. Religious pluralism contains many problems, including theological problems (Khaerurrozikin, 2015).

In the answer to the portfolio of pluralism also known from the pros and cons of the opinions of religious leaders, plurality must be seen as part of human life, which cannot be eliminated, but must be addressed wisely by students. Violence in the name of Islam in Indonesia, of course, contrary to the values contained in the teachings of Islam itself that Islam is a universal religion that upholds human values, equality of rights and tolerance. In the student's answer, it can be concluded that the true nature of pluralism is not like Hick's concept of religious pluralism (Hick, 1989), but the value of tolerance with mutual respect among religious people and not recognizing all the same religions and all true religions. In rejecting religious pluralism, in the sense of the word as a doctrine and understanding that says all religions are true, Muslims do not reject religious diversity. This is because in Islam there is no compulsion, Islam gives freedom to followers of other religions (Muammar, 2012). Islam does not adhere to the notion of religious pluralism (the truth of all religions), but upholds pluralism, namely the value of tolerance towards other religions both when Muslims are a minority and as a majority. Because in the hadith as well as in the history of Islamic civilization, Muslims have carried out peaceful lives among religious believers (Khaerurrozikin, 2015). In this case the perspective of student answers can be analyzed that students are predicted to be able to deliver pluralism that supports toll and good behavior with followers of other religions.

The awareness revealed in the portfolio of student analysis is that they understand that the context of interfaith interaction, Indonesian people are known to have their own value system so they can tolerate various kinds of diversity that exist in society. That each community has a value system that is believed, obeyed and implemented in order to maintain harmony in the community. Students also recognize traditional wisdom values. Traditional wisdom is known that students from portfolio expressions are all forms of knowledge, belief, understanding or insight, as well as customs or ethics that guide human behavior in the lives of ecological communities that involve good relations among fellow humans, also among all inhabitants of ecological communities (Maxwell, 1984) that students know that traditional wisdom needs to be lived out, practiced, taught, and passed down from one generation to the next, including it as one generation and passing on to students in the class. That the value of local wisdom that is still valid in Indonesian society has a role to encourage harmony in the life of peace among religious communities and to stabilize the diversity and integrity of the country and students play a role in continuing those values.

In the student portfolio, it is known that they recognize that the Indonesian community is a plural society and multicultural society. Students recognize that community pluralism is one of the main characteristics of the 
multicultural nation of Indonesia, a concept that promotes cultural pluralism. Culture is a term that refers to all symbolic aspects that can be learned in society, including belief, art, morality, law and customs (Firdausia, 2013). That students by studying and understanding the teachings of other religions are allowed to add insight into science about religion and not to look for weaknesses or find reasons to blaspheme it. Understanding and mastery of the teachings of other religions does not mean doubting the religion embraced, but rather to better understand the model of thinking of a person with the concept of divinity that is believed. That a believer who believes in his true religion will be more busy in carrying out religious guidance, collecting the coffers of good deeds. Religious Pluralism is better than one religion. With one religion the conditions of competing in various virtues will not be created. tolerant and complementary attitudes are clearly better than opposing attitudes from dozens of religions (Mahfudin, 2012).

As a religion teacher, students can be seen from the portfolio results that one of the important and strategic social institutions to instill a construct that is more sympathetic and empathetic towards the existence of other religions is education and he is in the world of Islamic education. with phenomena in society (Arifin, 2009). Thus, early Islamic education is very important to build Islamic human resources that are tolerant and broad-minded. we together to cultivate an attitude of openness, accept differences, and respect religious pluralism, along with loyalty and commitment to each other's religions is a shared responsibility. The process of learning and internalizing religious values at the institution of education can be done by improving religious learning material (Azzuhri, 2012). Understanding of pluralism from an early age can form a person who is tolerant, mutual respect, and rejects violence, so that all things that can lead to inter-religious conflict can be prevented and overcome. And this is an important estuary for students to be given the pluralism insertion as a candidate for religious teachers to be able to be wise and spread the skill to students later on, and of course the beginning of the pluralism perspective building in the teacher itself.

\section{Conclusion}

As a candidate for mastery and the application of teacher/ICT08 professional courses, learning and learning/ PAI 210, learning resources and media PAI/PAI21, learning design PAI/PAI24, development of Quranic material Hadist MTs MA/PAI08 Subjects of teaching/ICT professors08, study and learning/PAI 210, learning resources and media PAI/PAI21, learning design PAI/PAI24, development of the material of the Koran Hadith MTs MA/PAI08 is the capital for prospective religious teachers where in a logical, professional, personal and social manner is the provision of being the main religious teacher level of MTs/MA. The masters of Pluralism do not mean recognizing all religions equally and correctly but tolerance between religious people, mutual respect and respect for differences (religious beliefs) is an understanding that needs to be united from the insertion of PAI courses and from answers from student pluralism "there is a perspective that emerges from the portfolio that they can distinguish between pluralism-sensitive activities or behaviors and not sensitive to pluralism". Besides they understand and are expected to be able to apply the subjects of their study courses, students can also be predicted as students who have a high sensitivity to pluralism, where pluralism will be able to reduce conflict when problems occur in the future community. Being accustomed to the theme of pluralism will not make them wonder again about the differences in religion and belief, they could be coupled together in one particular assembly. Religious teachers in the future are predicted to be required to transmit the concept of pluralism while Islam is the only religion that is respected by Allah, but Islam upholds pluralism (in terms of inter-religious tolerance). The 
concept of pluralism must be properly understood and executed properly.

Students can transmit the concept of pluralism in Indonesia can be implemented by recognizing the existence of other religions, giving the right to coexist with each other adherents, avoiding violence by not destroying places of worship of other religious people, not imposing will on followers of other religions, acknowledging about the many ways that humans can take and the command to compete in virtue. If the concept of pluralism is carried out well by every believer, then divisions and disputes between religious communities can be overcome and the integrity of NKRI will be maintained. And religious teachers will be a bastion of tolerance among religious people in the future not as a trigger for conflict likes the vital role of teachers in strengthening and promoting education.

Mastery of the teaching profession/ICT08, learning and learning/PAI 210, learning resources and media PAI/ PAI21, learning design PAI/PAI24, development of Quranic material Hadist MTs MA/PAI08 Matter of teacher/ ICT profession lectures, learning and learning/PAI 210, sources and learning media PAI/PAI21, learning design PAI/PAI24, development of the material of the Quran Hadist MTs MA/PAI08 as part of the curriculum undertaken by PAI majors students should be understood thoroughly so that it can serve as capital for implementing PAI learning at the MTs/MA level and bringing the value of religious pluralism is a natural reality that must be understood and carried out by every religious community especially students as PAI religious teachers. That religious teachers through the sensitivity of pluralism will be able to become social control in carrying out religious life in the community and the country. One of the things that can be done to foster pluralism among Muslims can be done with Islamic education early on, education in primary and secondary schools. Pluralism-based Islamic education by highlighting several characters including education that fosters tolerance, education that instills democracy and education that reflects the ideals of Islam and a democratic country. With this education system students are equipped with an attitude of empathy, sympathy, solidarity, justice, and tolerance towards others through prospective teachers whose neighbors have been equipped with concepts, values, and implementation of pluralism in everyday life.

Active debate for pluralism in teaching student in teacher profession is effective for increasing understanding world view of pluralism when they was studying other subject likes ICT08 and others. It's according providing games that embed developmentally into school classrooms more feasible and impactful (Hulse et al., 2019) likes active debate method as technology in instructional learning for increasing understanding and model leaning.

\section{References}

Afrizal J. (2011). Demokrasi Melahirkan Pluralisme; Bahaya Dalam Toleransi Umat Beragama.

Al-Banna G. (2006). Doktrin Pluralisme dalam Al-Qur'an, Jakarta: Jakarta: Menara.

Allen-Lyall B. (2018). "Helping students to automatize multiplication facts: A pilot study", International Electronic Journal of Elementary Education, Vol. 10, No. 4, pp. 391-396, doi: 10.26822/iejee.2018438128.

Alruthia Y., Alhawas S., Alodaibi F., Almutairi L., Algasem R., Alrabiah H. K. and Ghawaa Y. et al. (2019). "The use of active learning strategies in healthcare colleges in the Middle East", BMC Medical Education, Vol. 19, No. 1, pp. 1-10, doi: 10.1186/s12909-019-1580-4.

Arifin S. (2009). "Construction of pluralism discourse in Indonesia”, Humannity, Vol. 5, No. 1, pp. 25-30.

As'ad M. (2012). "Pluralisme Agama Dalam Pandangan Islam”, Akademika, Vol. 17, No. 1.

Auerbach A. J. J. and Andrews T. C. (2018). "Pedagogical knowledge for active-learning instruction in large undergraduate biology courses: A large-scale qualitative investigation of instructor thinking”, International Journal of STEM Education, Vol. 5, No. 1, available online at: https://doi.org/10.1186/s40594-018-0112-9.

Azzuhri M. (2012). “Konsep Multikulturalisme Dan Pluralisme Dalam Pendidikan Agama”, Forum Tarbiyah, Vol. 10, No. 1.

Barnett R. (2019). "University challenge: Division, discourse and democracy", Postdigital Science and Education, doi: 10.1007/s42438-019-00044-z. 
Diamandopoulos K. and Green J. (2018). "Down syndrome: An integrative review”, Journal of Neonatal Nursing, Vol. 24, No. 5, pp. 235-241, doi: 10.1016/j.jnn.2018.01.001.

Dy-Boarman E. A., Nisly S. A. and Costello T. J. (2018). "It's no debate, debates are great", Currents in Pharmacy Teaching and Learning, Vol. 10, No. 1, pp. 10-13, doi: 10.1016/j.cptl.2017.09.016.

Firdausia (2013). “Al Quran Menjawab Tantangan Pluralisme Terhadap Kerukunan Umat Beragama”, Ulul Albab., Vol. 4 , No. 1.

Fitriyani (2011). "Pluralisme Agama-Budaya dalam Perspektif Islam”, Jurnal Al- Ulum, Vol. 11, No. 2.

Fowler R. C. (2016). "Reframing the debate about the relationship between learning and development: An effort to resolve dilemmas and reestablish dialogue in a fractured field", Early Childhood Educ. J., pp. 1-8, doi: 10.1007/s10643-015-0770-x.

Ghislaine Gueudet, Marianna Bosch, Andrea A. diSessa, O. N. K. and L. V. (2016). "Transitions in mathematics education: The panel debate", in: G. Gabriele Kaiser (Ed.), ICMI-13 Monograph, Faculty of Education, Didactics of Mathematics, Universität Hamburg, Hamburg, pp. 101-117.

HM. Yasin T. (2003). "Pluralisme agama sebuah keniscayaan”, Journal Substantia., Vol. 15, No. 1.

Hulse T., Daigle M., Manzo D., Braith L., Harrison A. and Ottmar E. (2019). "From here to there! Elementary: A game-based approach to developing number sense and early algebraic understanding", Educational Technology Research and Development, Vol. 67, No. 2, pp. 423-441, doi: 10.1007/s11423-019-09653-8.

Ioannis Doumanis, Daphne Economou and Gavin Robert Sim S. P. (2019). "The impact of multimodal collaborative virtual environments on learning: A gamified online debate", Computers \& Education, pp. 1-32, doi: 10.1016/j.compedu.2018.09.017.

Jamaludin M. S. (2013). "Respon Ulama Kontemporer Menanggapi Beberapa Isu dalam Pluralisme Agama di Malaysia", TOLERANSI, Vol. V, No. 2.

Khaerurrozikin A. (2015). "Problem Sosiologis Pluralisme Agama di Indonesia”, Journal Kalimah, Vol. 13, No. 1.

Lane M. A. K. and S. (2019). "After the content course: An expert-novice study of disciplinary literacy practices”, Journal of Social Studies Education Research, Vol. 10, No. 2, pp. 1-30, available online at: http://jsser.org/index.php/jsser/issue/current.

Madjid N. (1992). Islam Doktrin dan Peradaban, Jakarta: Paramadina.

Mahfudin A. (2012). “Konsep pluralisme agama dalam al-qur'an dan penafsirannya”, Religi: Jurnal Studi Islam, Vol. 3 , No. 2.

Maxville V. (2010). “eResearch bootcamp: Grooming next-gen researchers”, Procedia Computer Science, Vol. 1, No. 1, pp. 885-894, doi: 10.1016/j.procs.2010.04.097.

Mikerova G., Sergeeva B., Mardirosova G., Kazantseva V. and Karpenko A. (2018). "Learning environment affecting primary school student's mental development and interest", International Electronic Journal of Elementary Education, Vol. 407-414, No. 10, p. 4, doi: 10.26822/iejee.2018438130.

Nasrudin I. H. S. (2015). "Development of an integrated anti-corruption education model in al-islam learning and about Muhammadiyah at Muhammadiyah Purworejo University", Cakrawala, Vol. X, No. 1, pp. 31-43.

Peasah S. K. and Marshall L. L. (2017). "The use of debates as an active learning tool in a college of pharmacy healthcare delivery course", Currents in Pharmacy Teaching and Learning, Vol. 9, No. 3, pp. 433-440, doi: 10.1016/j.cptl.2017.01.012.

Pilkington R. M. and Walker S. A. (2003). "Facilitating debate in networked learning: Reflecting on online synchronous discussion in higher education”, Instructional Science, Vol. 31, No. 1-2, pp. 41-63, doi: 10.1023/A:1022556401959.

Spence C. (2019). “'Judgement' versus 'metrics' inhigher education management”, Higher Education, Vol. 77, pp. 761-775, doi: 10.1007/s10734-018-0300-z.

Stapp A. C. and Karr J. K. (2018). "Effect of recess on fifth grade students' time on-task in an elementary classroom", International Electronic Journal of Elementary Education, Vol. 10, No. 4, pp. 449-456, doi: 10.26822/iejee.2018438139.

Sunley R., Harding L. and Jones J. (2019). "Realising creativity in management education: Putting student energy into action",. International Journal of Management Education, Vol. 17, No. 2, pp. 172-181, doi: 10.1016/j.ijme.2019.02.007.

Thabathaba'I M. H. (1883). al-Mizan fi Tafsir al-Qur'an, Juz II, Qum al-Muqaddas, Iran: Jama'at al-Mudarrisin fi Hauzati al-Ilmiah. Thoha A. M. (2007). Tren Pluralisme Agama Tinjauan Kritis, Jakarta: Prespektif. 